\title{
A Brief Study on Mechanical Properties of Silica Fume Light Weight Aggregate (Pumice) Concrete
}

\author{
N.Sivalingarao ${ }^{1}$ and N.Manju \\ ${ }^{I}$ Dy.Exe.Engineer JNTUA Anantapuramu, ${ }^{2}$ Er, Vijayanirman, Banglore.
}

\begin{abstract}
Light weight aggregate concrete mixes can be used for high raised civil engineering structures, heavy constructions like bridges, dams etc. Architectural features and other cost effective projects is to be defined on certain aspects like proportions of Light weight aggregate. Water cement ratio, curing periods ,Mixing procedures, compaction methods, shuttering and de shuttering etc.Pumice stone is originally of volcanic origin with bulk density in the region of 400 to $800 \mathrm{~kg}$ per cubic meter and with moderately strong structure make a satisfactory concrete with a density of 550 to $1200 \mathrm{~kg}$ per cubic meter.

In this present investigation Mix design for $M_{20}$ concrete has been designed with natural aggregate, fine aggregate, cement .The normal aggregate has been replaced with 100\% pumice aggregate by volume and for this replacements cement is replaced with silica fume in various proportions $(5,8,10,15$ and $20 \%)$ by weight. The mechanical properties like compressive strength, flexural strength, and Split tensile strength increase at $10 \%$ replacement of cement by silica fume.
\end{abstract}

Keywords: Pumice aggregate, Volcanic, Natural

\section{Introduction}

Pumice is a natural aggregate of abundant resource around the world and it is environmentally friendly. However, pumice is far from being fully utilized in lightweight concrete at the time being. Concrete structures are generally designed to take advantage of its compressive strength. The primary structural property of concrete that a concrete designer is generally concerned is the compressive strength of concrete at a specific age. Pumice is the only rock that floats on water, although it eventually becomes waterlogged and sink. Since pumice is a volcanic rock, and retains its useful properties only when it is young and unaltered, pumice deposits are found in areas with young volcanic fields. Worldwide, over 50 countries produce pumice products. The largest producer is Italy, which dominates pozzolana production. Other major pumice producers are Greece, Chile, Spain, Turkey, and the United States. Pumice and pumicite are used to make lightweight construction materials. About three-quarters of pumice and pumicite is consumed annually for this purpose.

\section{Literature}

Weigler, H. and Karl, S. Stahlleichtbeton [1] reported that Air entraining agents can be used with Light Weight Aggregate Concrete. Its use reduces the density proportionally to the weight of the paste it replaces, enhances the workability and reduces the segregation and bleedings. According to LCI[2] and CEB/FIB model code for concrete structures[3] Very often, air-entraining agents are used to provide higher frost resistance concrete. Although structural lightweight concrete is usually defined as a concrete with an oven-dry density of no greater than $2000 \mathrm{~kg} / \mathrm{m}^{3} . \mathrm{T}$. Ashworth, E. Ashworth [27] reported that Thermal conductivity of concrete increases with increasing moisture content. Since water has conductivity about 25 times that of air, it is clear that when the air in the pores has been partially displaced by water or moisture, the concrete must have greater conductivity. According to Euro code No. 2 Part $1-4[28]$ also structural lightweight concrete is usually defined as a concrete with an oven-dry density of no greater than $2000 \mathrm{~kg} / \mathrm{m}^{3}$, there are variations in certain parts of the world. A. Mor [29] reported that LWCs have certain properties that are distinctly different from normal weight concrete. In addition to low unit weight, better reinforcing steel-concrete bond, durability performance, tensile strain capacity, and fatigue resistance make it preferable to normal weight concrete.

\section{Object and Scope of Investigation:}

a. To conduct the feasibility study of producing pumice concrete with Silica fume admixture.

b. To investigate the mechanical properties of pumice aggregate concrete, such as density, compressive strength, tensile strength, flexural strength and modulus of elasticity. 


\section{Experimental Investigation: \\ Cement:}

Locally available Ultratech Ordinary Portland Cement (OPC) of 43 grade of Cement Brand conforming to ISI standards has been procured and various tests have been carried out according IS: 8112-1989 from them it is found that

a) Specific gravity of Cement is 3.06

b) Initial and Final setting times of Cement are $45 \mathrm{~min}$ and $420 \mathrm{~min}$ respectively

c) Fineness of cement is $3 \%$

\section{Fine Aggregate:}

The locally available natural river sand is procured and is found to be conformed to grading zone-II .

a) Specific Gravity of fine aggregate is 2.60

b) Fully compacted density of fine aggregate is $1766 \mathrm{~kg} / \mathrm{m}^{3}$

c) Partially compacted density of fine aggregate is $1500 \mathrm{~kg} / \mathrm{m}^{3}$

d) Fineness Modulus of Fine Aggregate is 3.20

\section{Coarse Aggregate (Granite) and Light Weight Aggregate (Pumice):}

Machine Crushed granite aggregate confirming to IS 383-1970 consisting $20 \mathrm{~mm}$ maximum size of aggregates has been obtained from the local quarry. It has been tested for Physical and Mechanical Properties such as Specific Gravity, Sieve Analysis, Density values and the results are as follows.

a) Specific Gravity coarse aggregate is 2.61

b) Fully compacted density of coarse aggregate is $1690 \mathrm{~kg} / \mathrm{m}^{3}$

c) Partially compacted density of coarse aggregate is $1466 \mathrm{~kg} / \mathrm{m}^{3}$

d) Fineness Modulus of Coarse Aggregate 9.09

Light weight aggregate (pumice) is procured from Turkey. The size of light weight aggregate is $20 \mathrm{~mm}$. Some of its properties are as follows

a) Specific Gravity coarse aggregate is 1.14 .

b) Fully compacted density of Lightweight coarse aggregate is $85 \mathrm{~kg} / \mathrm{m}^{3}$

c) Loose density of Light weight coarse aggregate is $140 \mathrm{~kg} / \mathrm{m}^{3}$

d) Water:

e) Potable water has been used in this experimental program for mixing and curing.

f) Super Plasticizer:

g) Super Plasticizers (SP-430) are new class of generic materials which when added to the concrete cause increase in the workability.

In the present investigation $\mathrm{M}_{20}$ grade of concrete is considered and replacement of conventional coarse aggregate by $100 \%$ pumice aggregate and replacing the cement by Silica fume at percentages of $0,5,8,10,15$ $\& 20$ by weight of cement.

\section{Discussion Of Test Results}

The cube compressive strength results with 100\% natural aggregate being replaced by $100 \%$ pumice and with different percentage replacements of cement by silica fume are presented in Table.1. it is observed that there is an increase in compressive strength for replacement of cement by silica fume up to $10 \%$ and from there the strength gets decreased. Hence $10 \%$ is the optimum for replacement of cement by silica fume. The cylinder compressive strength results with $100 \%$ natural aggregate being replaced by $100 \%$ pumice and with different percentage replacements of cement by silica fume are presented in Table.2. it is observed that there is an increase in compressive strength for replacement of cement by silica fume up to $10 \%$.Hence $10 \%$ is the optimum. Split Tensile Strength, Flexural Strength and Moment carrying capacity of slabs also follows same pattern.

Table 1. Densities of Silicafume Pumice Concrete

\begin{tabular}{|l|l|l|}
\hline S No & Identification Mark & Density $\mathrm{In} \mathrm{Kg} / \mathrm{m}^{3}$ \\
\hline 2 & $\mathrm{P}$ & 1711.11 \\
\hline 3 & $\mathrm{P}_{5}$ & 1760.00 \\
\hline 4 & $\mathrm{P}_{8}$ & 1777.78 \\
\hline 5 & $\mathrm{P}_{10}$ & 1800.00 \\
\hline 6 & $\mathrm{P}_{15}$ & 1681.48 \\
\hline & $\mathrm{P}_{20}$ & 1665.19 \\
\hline
\end{tabular}


Table 2. Cube Compressive Strength

\begin{tabular}{|l|l|l|}
\hline S No & Identification Mark & $\begin{array}{l}\text { Compressive Strength (28 } \\
\text { Days)in N/mm }\end{array}$ \\
\hline 1 & $\mathrm{P}$ & 8.73 \\
\hline 2 & $\mathrm{P}_{5}$ & 8.40 \\
\hline 3 & $\mathrm{P}_{8}$ & 9.89 \\
\hline 4 & $\mathrm{P}_{10}$ & 10.02 \\
\hline 5 & $\mathrm{P}_{15}$ & 7.62 \\
\hline 6 & $\mathrm{P}_{20}$ & 7.42 \\
\hline
\end{tabular}

Table 3. Cylinder Compressive Strength

\begin{tabular}{|l|l|l|}
\hline S No & Identification Mark & $\begin{array}{l}\text { Compressive Strength (28 Days) } \\
\text { in N/mm }\end{array}$ \\
\hline 1 & $\mathrm{P}$ & 8.60 \\
\hline 2 & $\mathrm{P}_{5}$ & 8.71 \\
\hline 3 & $\mathrm{P}_{8}$ & 9.17 \\
\hline 4 & $\mathrm{P}_{10}$ & 9.51 \\
\hline 5 & $\mathrm{P}_{15}$ & 7.75 \\
\hline 6 & $\mathrm{P}_{20}$ & 6.90 \\
\hline
\end{tabular}

Table 4. Modulus of Elasticity

\begin{tabular}{|l|l|l|l|}
\hline S No & $\begin{array}{l}\text { Identification } \\
\text { Mark }\end{array}$ & $\begin{array}{l}\text { Approach-I YoungsmodulusE }=5000 \sqrt{f_{c k}} \\
\text { in N/mm }\end{array}$ & $\begin{array}{l}\text { Approach-II Youngsmodulus } \\
\mathrm{E}=\mathrm{K}_{1} \times K_{2} \times 1.486 \times 10^{-3} \times \sigma_{\mathrm{b}}{ }^{1 / 3} \gamma^{2} \\
\text { In N/mm }\end{array}$ \\
\hline 1 & $\mathrm{P}$ & $1.48 \times 10^{4}$ & $8.75 \times 10^{3}$ \\
\hline 2 & $\mathrm{P}_{5}$ & $1.45 \times 10^{4}$ & $9.11 \times 10^{3}$ \\
\hline 3 & $\mathrm{P}_{8}$ & $1.57 \times 10^{4}$ & $9.82 \times 10^{3}$ \\
\hline 4 & $\mathrm{P}_{10}$ & $1.58 \times 10^{4}$ & $1.01 \times 10^{4}$ \\
\hline 5 & $\mathrm{P}_{15}$ & $1.38 \times 10^{4}$ & $8.06 \times 10^{3}$ \\
\hline 6 & $\mathrm{P}_{20}$ & $1.36 \times 10^{4}$ & $7.83 \times 10^{3}$ \\
\hline
\end{tabular}

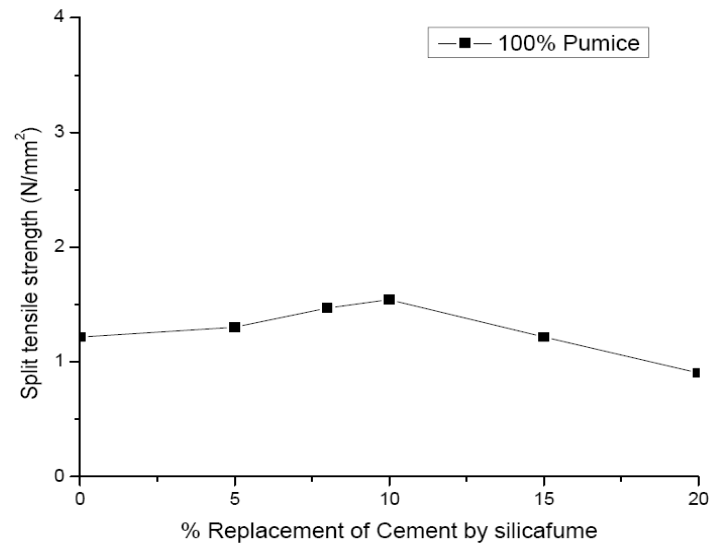

Fig.1. Split tensile strength Vs Replacement of Cement by Silica fume

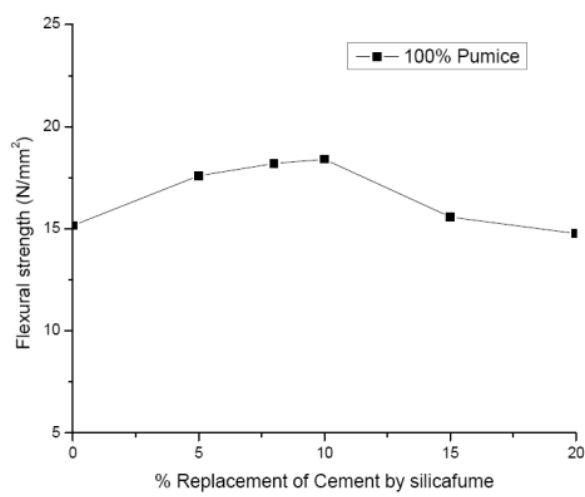

Fig. 2 Flexural Strength Vs Replacement of cement by silicafume 


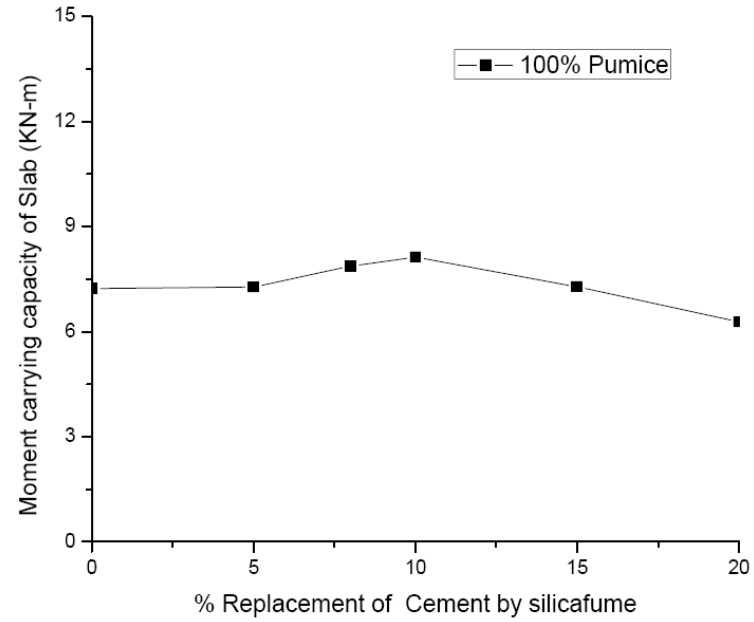

Fig.4 . Moment carrying capacity of slab Vs Replacement of cement by silicafume

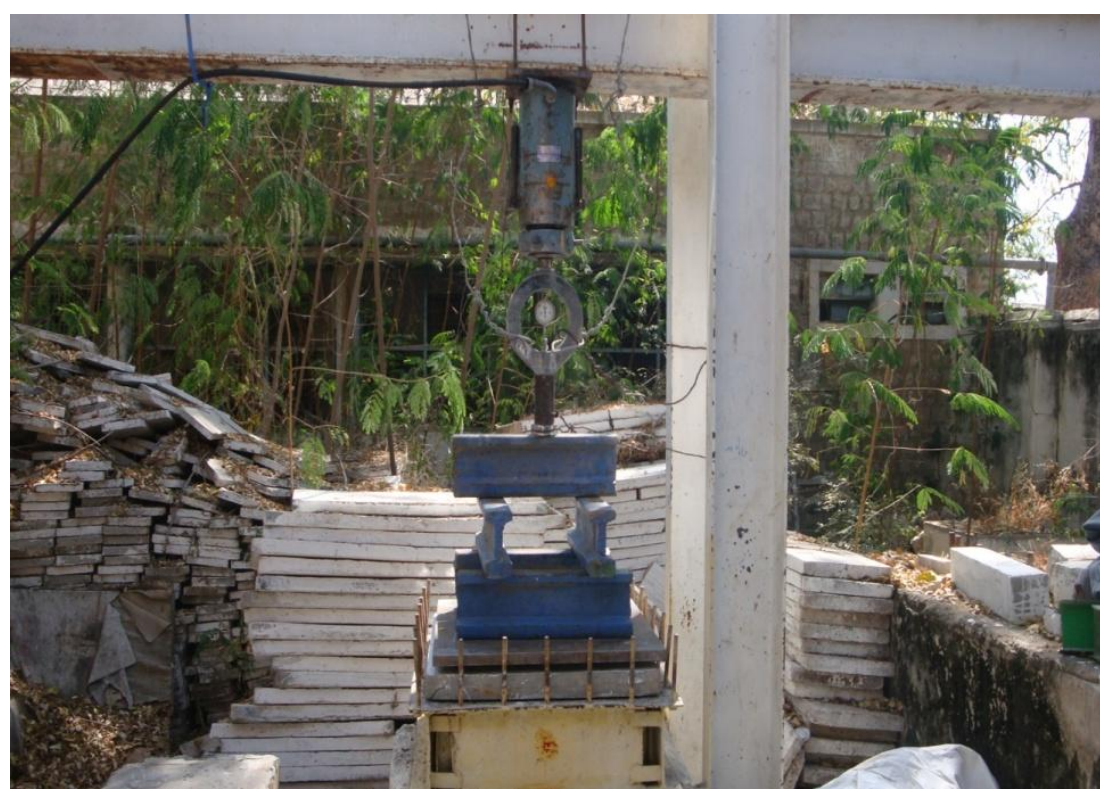

Plate 1. Slab Testing Arrangement

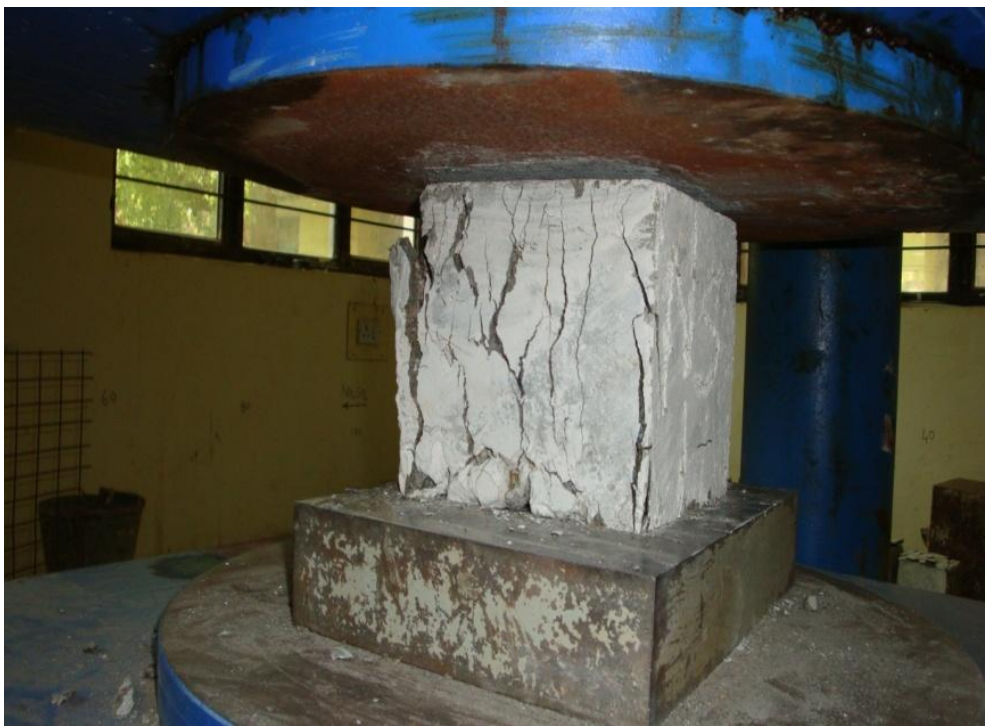

Plate 2. Cube under Compression Testing Machine 


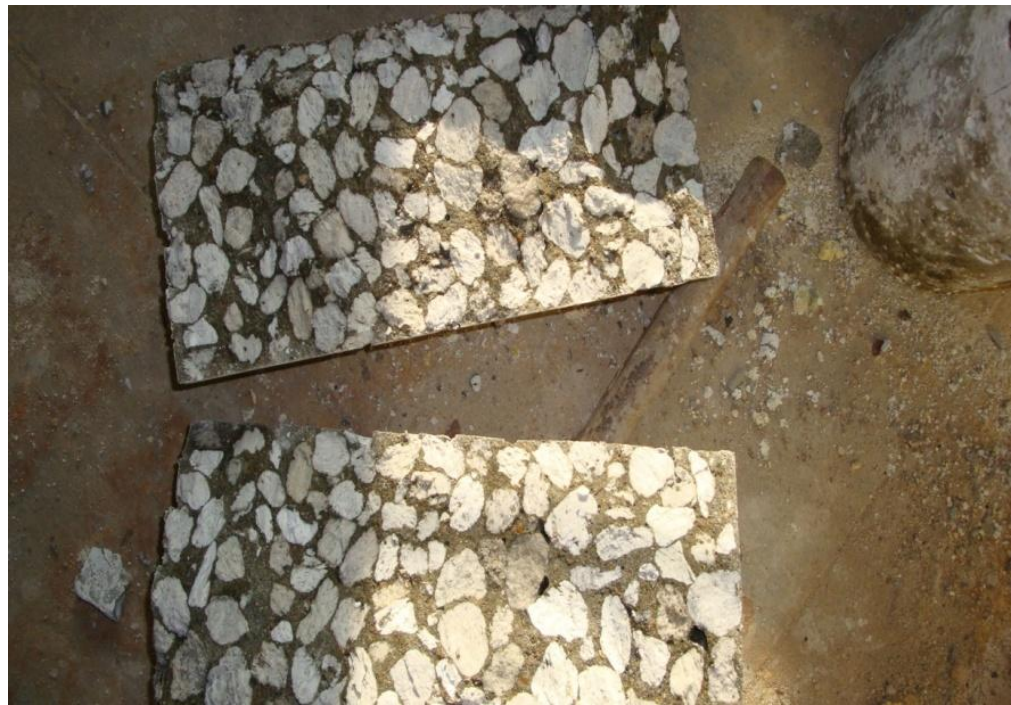

Plate 3. Split Tensile Strength Specimen

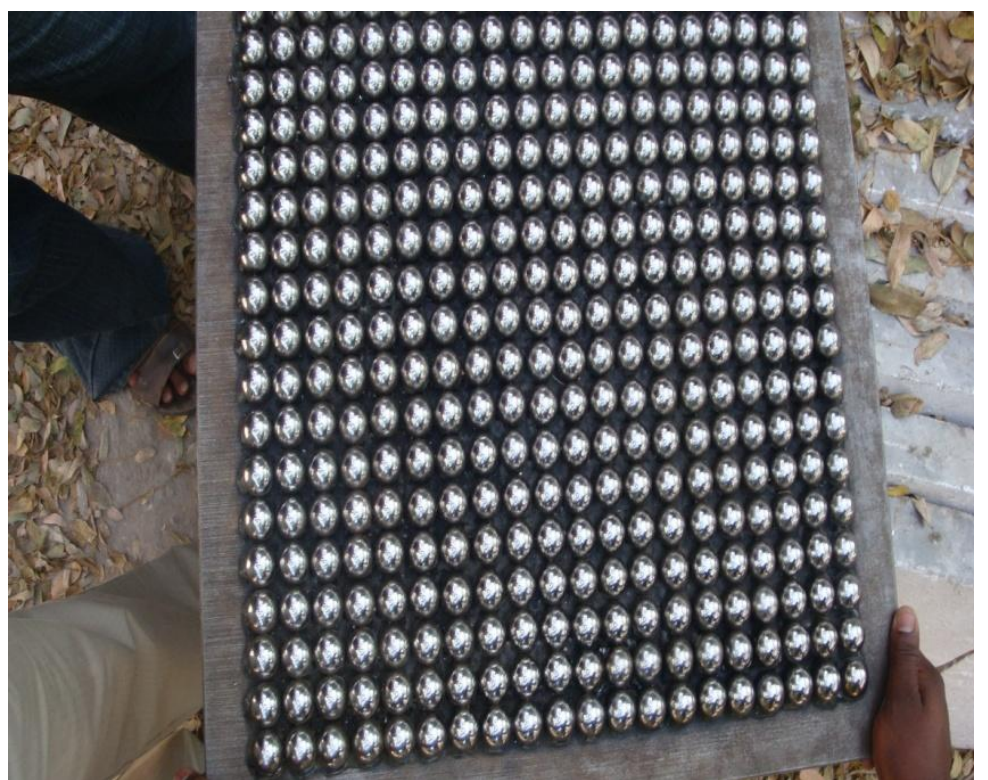

Plate 4. U D L Arrangement for slab Testing.

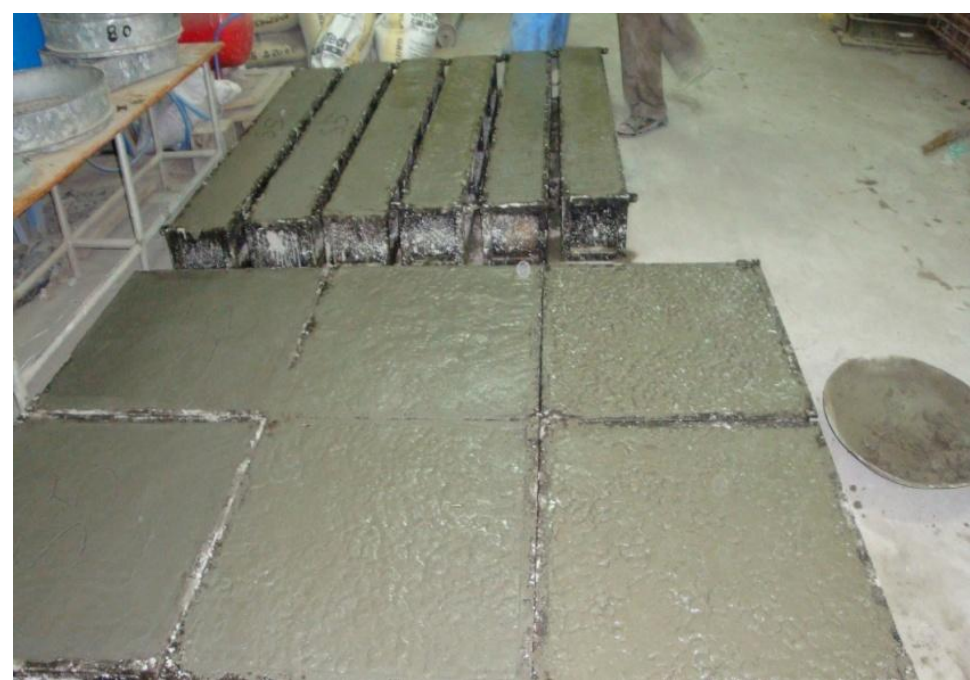

Plate 5. Casting of Specimens 


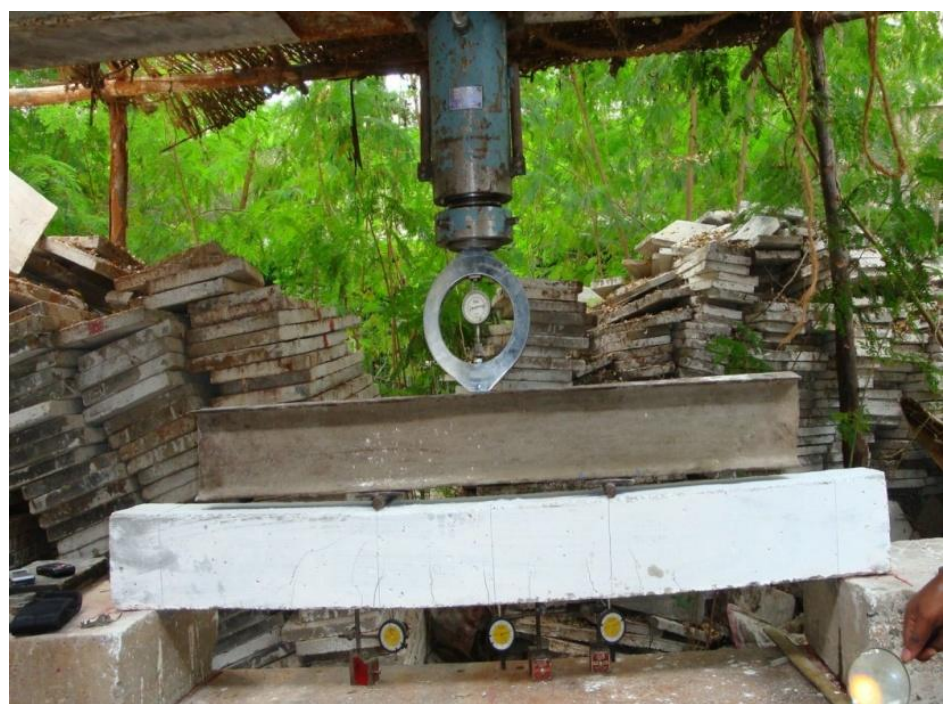

Plate 6. Flexural Strength of Beam

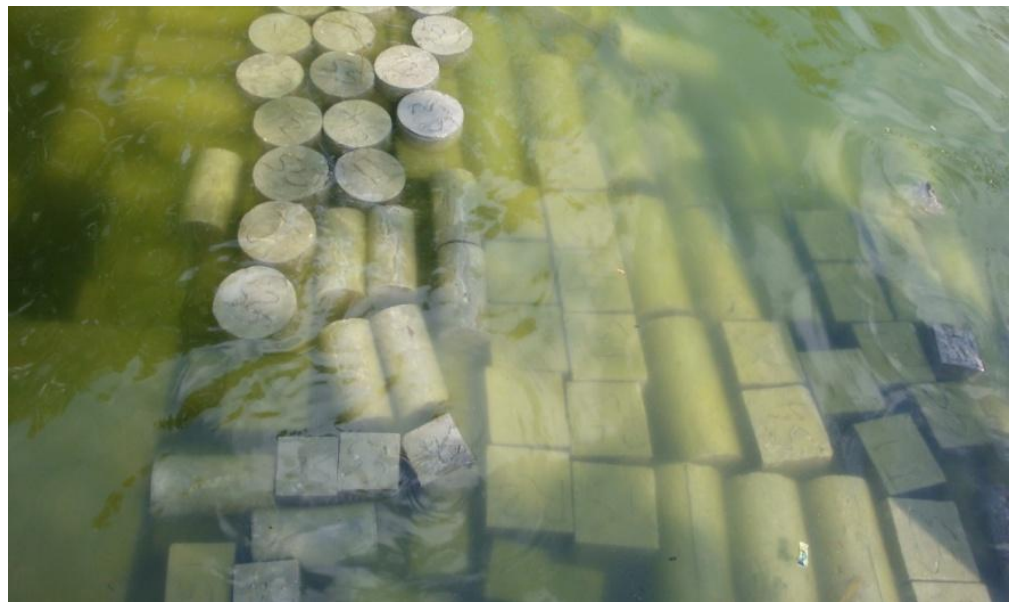

Plate 7. Curing of Specimens

\section{Conclusions}

1. The compressive strength of concrete is found to $8.73 \mathrm{MPa}$ as the pumice content is 100 percent.

2. The cylinder compressive strength of pumice concrete is seen to increase with the silicafume content and reaches an optimum values between 5 to $10 \%$ and afterwards gets decreased for various contents of pumice.

3. With the increase in pumice contents the deflections of beams, slabs etc., are found to increase.

4. Based on the experimental investigations it is concluded that pumice light weight aggregate is in no way inferior to other manufactured, developed aggregate like cold bonded, sintered artificial aggregates.

\section{References}

[1]. Weigler, H. and Karl, S. Stahlleichtbeton. Bauverlag GMBH, Wiesbaden and Berlin, pp. 38-43, 1972.

[2]. Terminology and Definition of Lightweight Concrete, Recommendation LC1, 1st ed., RILEM, Brussels, 1975.

[3]. T. Ashworth, E. Ashworth, Insulation Materials: Testing and Applications,Euro code No. 2 Part 1 - 4: The Use of Lightweight Aggregate Concretewith Closed Structure, Draft, June 1992, EEC. 